Acta Horticulturae et Regiotecturae 2

Nitra, Slovaca Universitas Agriculturae Nitriae, 2019, pp. 93-96

\title{
IRON AND MANGANESE IN WELL WATER: POTENTIAL RISK FOR IRRIGATION SYSTEMS
}

\author{
Jasna GRABIĆ*, Milica VRANEŠEVIĆ, Radoš ZEMUNAC, Senka BUBULJ, Atila BEZDAN, Milica ILIĆ \\ University of Novi Sad, Serbia
}

\begin{abstract}
In the light of climate changes and in order to achieve stable crop production, irrigation represents an inevitable measure. Apart from water quantity, water quality represents a matter of concern. The paper elaborates on the presence of iron and manganese, as the main factors of causing the clogging of irrigation systems. The examined well water samples were taken mainly from Serbia. Photometric methods were applied for determining iron and manganese, and sensors for $\mathrm{pH}$ and conductivity. The obtained values were later subjected to a classification for irrigation water and the well water samples were classified according to the given thresholds. Precise location and presentation of the obtained results were done using the Geographic information system. The research has shown that from the analysed well water, only in 6 samples iron concentrations were increased up to a level classified as "extreme restrictions," 4 samples as "warning," while 31 samples of water were "adequate for irrigation." Concerning manganese, in only one sample water was classified as "extreme restrictions," in 14 as "warning" and in 26 as "adequate for irrigation." pH and conductivity did not coincide with elevated concentrations of iron and manganese, but in the cases of exceeding thresholds, special attention should also be paid to these parameters.
\end{abstract}

Keywords: water quality, groundwater, irrigation, iron, manganese

Climate changes are manifested as more frequent extreme events, as heatwaves and phenomena of long-lasting drought periods, but also as extreme precipitation events (IPCC, 2014). All these events pose challenges for achieving stable and sustainable crop production. Increased water shortages, particularly in the spring and summer months, increase the water requirement for irrigation (Levidow et al., 2014). In Europe, the most negative effects for the continental climate were found in the Pannonian zone, which includes Hungary, Serbia, Bulgaria, and Romania. This region will suffer from increased incidents of heatwaves and droughts (Olesen et al., 2011).

In order to mitigate or even overcome water deficiency, irrigation has to be introduced. It is well known that agriculture accounts for $70 \%$ of global freshwater withdrawals. Presently irrigated agricultural production is estimated to account for $20 \%$ of the arable land and this share is expected to be increased to $47 \%$ by 2030 , and irrigated food production will be increased by more than 50 percent by 2050 (FAO, 2017). These facts point to the significance of irrigation as an agro-technical measure. Apart from water quantity, the quality of water for irrigation is also very important. Water used for irrigation must have certain physical, chemical and mechanical properties, otherwise, it can cause damage to irrigated crops and human and animal health (Kaletova and Jurik, 2018) and soil. Despite the fact that intensive crop production assumes irrigation as an indispensable measure, it often faces many challenges. The overall problem of irrigation may be categorized in several aspects:
1. available water quality and quantity;

2. influence on cultivated plants;

3. influence of irrigation practices on soil conservation;

4. preservation of irrigation equipment during exploitation.

In order to perform successful irrigation practices, it is necessary to satisfy all the mentioned aspects. In this context, application of water quality classifications for irrigation plays an important role. According to Bortolini, Maucieri and Borin (2018), apart from agronomical and health and hygiene indicators, management quality indicators are also important assuming: parameters causing a negative effect on irrigation systems, where especially clogging needs to be resolved. Fe and $\mathrm{Mn}$ are considered to be essential elements/micronutrients for plants (Dalcorso et al., 2014; Rout and Sahoo, 2015), but their higher concentration above the allowed can be reflected through the negative effects on the soil, cultivated plants and clogging of irrigation equipment (Xiufu and Zinati, 2005), as well as aesthetic nuisance forming rusty deposits on the surrounding objects and plants.

In the province of Vojvodina, the water quality of surface water bodies in most cases is good and adequate for irrigation (Vranešević, Ilić and Bezdan, 2018; llić et al., 2019), except for some reaches of the Hydro System Danube-TisaDanube (Grabić et al., 2016). However, many farmers from the region, because of practical reasons, use groundwater. In such water, there could be a problem of increased salinity and the presence of $\mathrm{Fe}$ and $\mathrm{Mn}$, which is not only the

Contact address: Jasna Grabić, Ph.D., University of Novi Sad, Faculty of Agriculture, Department of Water Management; Trg. D. Obradovića 8, 21000 Novi Sad, Serbia, phone +381 2148534 12; e-mail: jasna.grabic@polj.uns.ac.rs 
problem for the region, but rather the general characteristic of groundwaters of the Pannonian Basin (Rowland et al., 2010).

In this study, the main focus was on determining the presence of $\mathrm{Fe}$ and $\mathrm{Mn}$ in groundwater used for irrigation and their spatial presentation using GIS tools. Furthermore, using current classification for irrigation, the intention has also been to assess potential risks for irrigational systems. Besides, values of $\mathrm{pH}$ and electrical conductivity (EC) were determined, as the most common and the most general parameters for irrigation water.

\section{Material and methods}

\section{Study area and well water sampling}

The study presents results of testing of 41 water samples of well water. The water was sampled in the territory of Serbia, mainly in the territory of the Autonomous Province of Vojvodina (northern part of Serbia), while several water samples are from countries from the region: Bosnia and Herzegovina, Montenegro and Slovakia. The scattered geographical position of samples was due to the intentions of individuals to invest or to enlarge irrigation systems, or as a control since the problems of water quality have been previously reported. The water samples were collected by the personal departure to the field, or with the help of associates (students, acquaintances, agricultural companies, etc.). The underground water was pumped out directly from wells, completely filling 1.5 I clean plastic bottles. The bottles were sealed and transported to the laboratory, where the samples were stored in the refrigerator below $8{ }^{\circ} \mathrm{C}$ prior to analysis. For each sample, the location of the well, from where the water was taken, was recorded. On the basis of the coordinates provided, maps with locations of sampled water were later produced.

\section{Methods for water quality analyses}

In each water sample there were detected the following parameters using appropriate equipment: $\mathrm{pH}$ - sensory method: $\mathrm{pH}$ meter, produced by TESTO Germany, measuring range $0-14$; EC - sensory method: EC meter, produced by EuTech, the Netherlands, measuring range 0-199.9 mS.cm ${ }^{-1}$; Fe and $\mathrm{Mn}$ - photometric methods: multiparameter photometer (produced by LOVIBOND, Germany, with detection limits of $0.02 \mathrm{mg} \mathrm{Fe} . \mathrm{I}^{-1}$ and $0.01 \mathrm{mg} \mathrm{Mn} . \mathrm{I}^{-1}$.

\section{Water quality standards}

There is no clearly defined categorization (classification) of the usability of water for irrigation in the legislation of the Republic of Serbia. In order to classify water samples into appropriate classes for irrigation, thresholds proposed by the Bortolini, Maucieri and Borin (2018) were used. Threshold values for examined irrigation water quality parameters, elaborated in this study, are given in Table 1, as well as some usual ranges for irrigation water proposed by FAO (Ayers and Wescot, 1985).

\section{GIS mapping and software}

Production of maps, containing locations of well water samples, was done using GIS tools. For this purpose, Quantum GIS software (version 2.16) was used. This is free software, which is used for editing, analysing and presenting geospatial data. Quantum GIS is a multiplatform application that runs on different operating systems, such as Mac OS, Linux, Microsoft Windows, and Android. Maps were generated using the World Geodetic System (WGS84). Besides the locations of the wells from which samples were taken, there are also stored values of examined water quality parameters in attribute tables. This enabled later production of maps for each water quality parameter, with the respect to water quality thresholds according to the chosen classification.

\section{Results and discussion}

The results of well water analysis are presented in Fig. 1-4, where different colours indicate water quality classes according to Bortolini, Maucieri and Borin (2018). Research results showed that Fe concentrations were in the range of less than 0.02 to $12.7 \mathrm{mg} \mathrm{Fe}^{-l^{-1}}$. The highest concentration of $12.7 \mathrm{mg} \mathrm{Fe} . \mathrm{I}^{-1}$ was measured in the sample collected from the well of the Faculty of Agriculture, the University of Novi Sad, Serbia (FAUNS, SRB), followed by Nitra (Slovakia) and KK Granicar (SRB) with values 8.59 and $8.3 \mathrm{mg} \mathrm{Fe}^{-1}{ }^{-1}$, respectively.

Concerning minimal values, 7 samples had concentration below the detection limit (i.e. $0.02 \mathrm{mg} \mathrm{Fe}^{-1}{ }^{-1}$ ). If mentioned extreme values are excluded, the average for other samples was $0.48 \mathrm{mg} \mathrm{Fe} . \mathrm{I}^{-1}$. Mn concentrations were in the range of $0.01 \mathrm{mg} . \mathrm{I}^{-1}$ to $4.1 \mathrm{mg}^{-1} \mathrm{l}^{-1}$. The highest concentration of Mn was in the sample collected in Nitra (Slovakia) of $4.1 \mathrm{mg} \mathrm{Mn.I}^{-1}$, followed by 0.75 (KK_Granicar, SRB) and 0.69 (Futog, SRB)

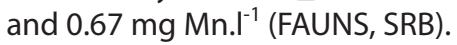

Table 1

Threshold values for irrigation water quality

\begin{tabular}{|c|c|c|c|c|c|}
\hline \multirow[t]{2}{*}{ Parameters } & \multirow[t]{2}{*}{ Units } & \multirow{2}{*}{$\begin{array}{c}\text { The usual values in irrigation } \\
\text { water } \\
\text { Ayers and Wescot, } 1985\end{array}$} & $\begin{array}{l}\text { Adequate for } \\
\text { irrigation }\end{array}$ & Warning & $\begin{array}{c}\text { Extreme } \\
\text { restrictions }\end{array}$ \\
\hline & & & \multicolumn{3}{|c|}{ Bortolini, Maucieri and Borin, 2018} \\
\hline pH & & $6.5-8.4$ & $6.00-8.00$ & $5.00-5.99$ & $<5.00$ \\
\hline EC & $\mathrm{mS} . \mathrm{cm}^{-1}$ & $0-3,000$ & $<700$ & $700-6,500$ & $>6,500$ \\
\hline $\mathrm{Fe}$ & mg..$^{-1}$ & $\max 5$ & $<0.50$ & $0.05-1.50$ & $>1.50$ \\
\hline Mn & mg.l ${ }^{-1}$ & $\max 0.2$ & $<0.10$ & $0.10-1.50$ & $>1.50$ \\
\hline
\end{tabular}




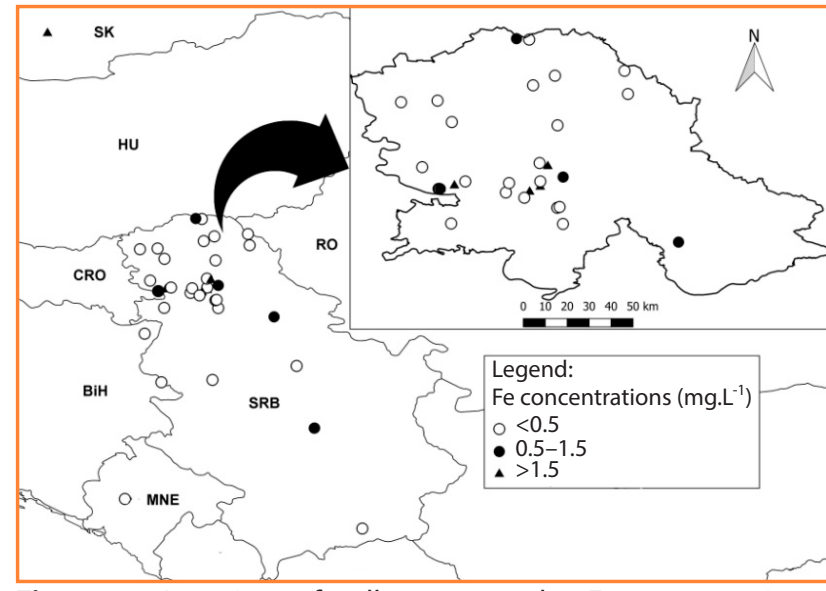

Figure 1 Locations of well water samples, Fe concentrations

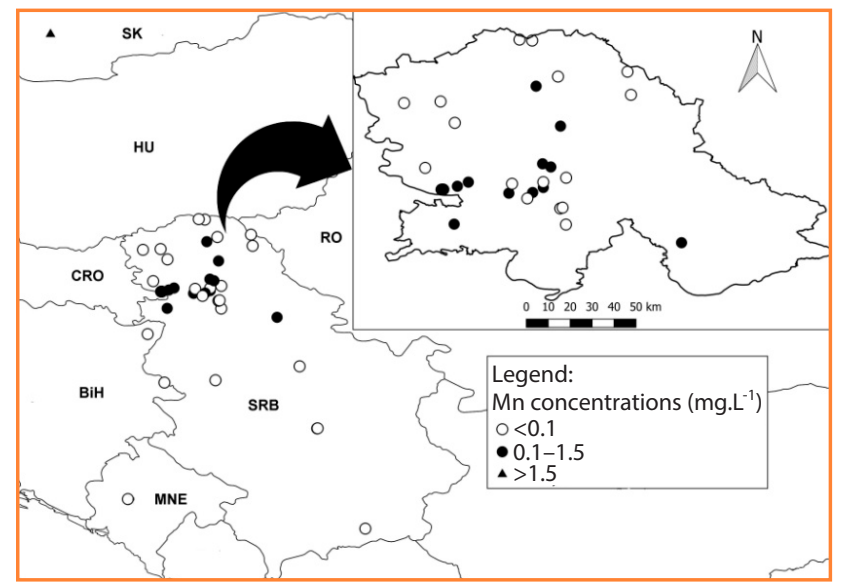

Figure 2 Locations of well water samples, Mn concentrations

The values of $\mathrm{pH}$ reaction were generally ranging within the posed thresholds. The highest concentration was detected in the sample from Bač (SRB) of 8.10 and Romania (SRB) of 8.06, while the lowest value was 6.51, measured in well water from Kać (SRB). Values of EC were in the range of 438 (Palić, SRB) to $3,120 \mathrm{mS} . \mathrm{cm}^{-1}$ (Romania, SRB).

The obtained results of measured parameters are in compliance with the findings obtained from the official network of wells for systematic control of groundwater in Serbia (RHMSS, 2010-2017) and results on the evaluation of groundwaters quality within 3 Vojvodinian regions. Moreover, the problem of elevated concentrations of Fe and Mn has also been discussed by Varsányi and Kovács (2006) and Rowland et al. (2010) and for the Pannonian Basin, as well as by Barloková and llavský (2018) for groundwaters in Slovakia.

The acidity and alkalinity indicator, $\mathrm{pH}$ value, rarely poses a problem in itself. Water used for irrigation should have a $\mathrm{pH}$ ranging from 6.5 to 8.4 , and if the $\mathrm{pH}$ is outside of these values, this may cause a nutritional imbalance or may contain a toxic ion, or even can lead to degradation of soil and irrigational equipment (Ayers and Wescot, 1985). Increasing the concentration of dissolved salts in the soil elevates the osmotic pressure of the soil solution and in such conditions, plants cannot adapt easily. Therefore, as the salt concentration (expressed as EC) in soil increases, water becomes less accessible to plants, even if the soil contains

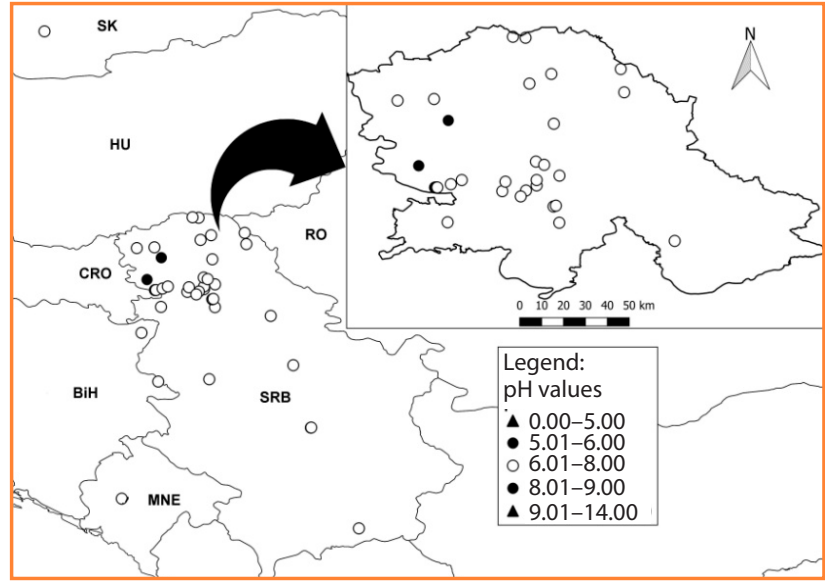

Figure 3 Locations of well water samples, $\mathrm{pH}$ value

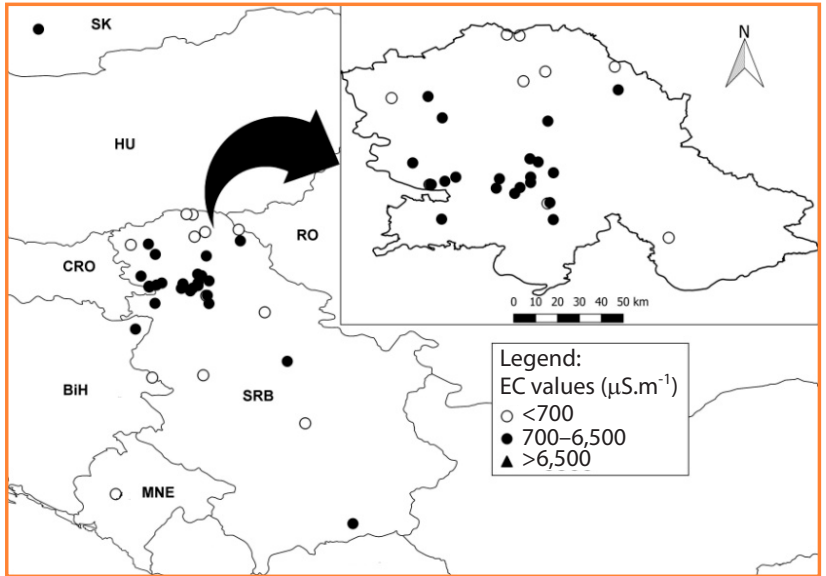

Figure 4 Locations of well water samples, EC value

significant amounts of water and looks moist. In general, $\mathrm{Fe}$ is not toxic to plants in aerated soils but can contribute to soil acidification and loss of availability of essential phosphorus and molybdenum. If irrigation by sprinklers is applied it may lead to Fe deposits on plants, equipment, and buildings. Concerning $\mathrm{Mn}$, it is toxic to a number of crops at a few-tenth to a few mg. $\mathrm{I}^{-1}$, but usually only in acid soils (Ayers and Wescot, 1985).

In situations where high $\mathrm{Fe}$ and $\mathrm{Mn}$ concentrations are found in irrigation water, some of the possibilities for their removal from the water should be considered. Therefore, in these cases, it is necessary to consider the following options:

1. possibilities for their removal from the well water;

2. to apply an adequate type of irrigation (e.g. not to use sprinkler irrigation);

3. to take care of sensitive crops.

However, if drip irrigation is practiced, there is a need for obligatory upgrading irrigation systems with appropriate filters. This research showed that Fe and Mn are present in a number of the well water samples. According to some estimates in Vojvodina Province, there is 950,200 ha of potential areas for irrigation (Potkonjak, Zoranović and Mačkić, 2010), and therefore examining water quality for irrigation must be an obligatory measure, in order to avoid 
losses of crop yields and the risk of malfunctioning of irrigational systems.

\section{Conclusion}

The research has shown that from the analysed well water, only in 6 samples Fe concentrations were increased up to a level classified as "extreme restrictions," 4 samples as "warning," while in 31 samples water was "adequate for irrigation". Concerning, $\mathrm{Mn}$ in only one sample, water was classified as "extreme restrictions," in 14 as "warning" and in 26 as "adequate for irrigation." The results of this research indicate that even the occurrence of higher concentrations of $\mathrm{Fe}$ and $\mathrm{Mn}$ is not frequent within the examined region; regular practice of assessing water quality for irrigation may prevent undesired effects on irrigation equipment, toxicity to plants and degradation of soil.

\section{References}

AYERS, R.S. - WESTCOT, D.W. 1985. Water Quality for Agriculture. FAO Irrigation and Drainage Paper 29 Rev. ${ }^{\text {st }}$, Rome : FAO. Available at: www.fao.org/3/T0234E/T0234E00.htm

BARLOKOVÁ, D. - ILAVSKÝ, J. 2018. Groundwater: An Important Resource of Drinking Water in Slovakia. In: Negm, A. - Zeleňáková, M. (eds). Water Resources in Slovakia: Part I. The Handbook of Environmental Chemistry, Springer, Cham. vol. 69, 2018.

BLUEWATERS. 2005. Project 353 Draft report: Sustainable solutions to improve quality of drinking water affected by high arsenic contents in 3 Vojvodinian regions. 2005, Book II: Groundwater sources Stadt Wien MA 31 - Water Management. Available at: http:// www.ekourbapv.vojvodina.gov.rs/wp-content/uploads/2018/09/ book2hydrogeology.pdf

BORTOLINI, L. - MAUCIERI, C. - BORIN, M. 2018. A Tool for the Evaluation of Irrigation Water Quality in the Arid and Semi-Arid Regions. In Agronomy, vol. 8, 2018, no. 23, pp. 1-15. https://www. mdpi.com/2073-4395/8/2/23

DALCORSO, G. - MANARA, A. - PIASENTIN, S. - FURINI A. 2014. Nutrient metal elements in plants. In Metallomics: Integrated biometal science, vol. 6, 2014, no. 10. doi:10.1039/c4mt00173g FAO. 2017. Water for Sustainable Food and Agriculture. A report produced for the G20 Presidency of Germany, Rome. ISBN 978-92-5-109977-3.

GRABIĆ, J. - BENKA, P. - BEZDAN, A. - JOSIMOV-DUNĐERSKI, J. SALVAI A. 2016. Water quality management for preserving fish populations within Hydro-system Danube-Tisa-Danube, Serbia. In Carpathian journal of earth and environmental sciences. vol. 11, 2016, pp. 235-243. www.ubm.ro/sites/CJEES/viewTopic. php?topicld $=613$

ILIĆ, M. - VRANEŠEVIĆ, M. - BEZDAN, A. - BLAGOJEVIĆ, B. 2019. Classification of Water Quality of Banat Watercourses in Serbia for the Needs of Irrigation. In Journal of Environmental Geography, vol. 12, 2019, no. 1-2, pp. 51-57. doi.org/10.2478/jengeo-2019-0006

IPCC. 2014. Climate change 2014: Synthesis report. Contribution of working groups I, II and III to the $5^{\text {th }}$ Assessment Report of the Intergovernmental Panel on Climate Change. Core Writing Team, R. K. Pachauri and L. A. Meyer, edsitors. Geneva (Switzerland): IPCC; p. 151. doi:10013/epic.45156.d001

KALETOVA, T. - JURIK, L. 2018. Quality of Water Required for Irrigation. In book: The Handbook of Environmental Chemistry Water Resources in Slovakia: Part I Assessment and Development. $1^{\text {st }}$ ed., Berlin, Heidelberg: Springer. doi: $10.1007 / 698 \quad 2017 \quad 214$

LEVIDOW, L. - ZACCARIA, D. - MAIA, R. - VIVAS, E. - TODOROVIC, M. - SCARDIGNO, A. 2014. Improving water-efficient irrigation: Prospects and difficulties of innovative practices. In Agricultural Water Management, vol. 146, 2014, pp. 84-94. ISSN 0378-3774. doi. org/10.1016/j.agwat.2014.07.012

OLESEN, J.E. - TRNKA, M. - KERSEBAUM, K.C. - SKJELVÅG, A.O. SEGUIN, B. - PELTONEN-SAINIO, P. - ROSSI, P. - KOZYRA, - MICALE J.F. 2011. Impacts and adaptation of European crop production systems to climate change. In European Journal of Agronomy, vol. 34, 2011, no. 2, pp. 96-112. ISSN 1161-0301. doi.org/10.1016/j. eja.2010.11.003

POTKONJAK, S. - ZORANOVIĆ, T. - MAČKIĆ, K. 2010. The irrigation influence on agricultural intensification in Serbia. In Economics of agriculture, International scientific meeting: Multifunctional agriculture and rural development $(\mathrm{V})$ - regional specifities, Banja Vrujci, Serbia, $2^{\text {nd }}-3^{\text {rd }}$, December 2010, special issue. Available at: www.ea.bg.ac.rs/index.php/EA/article/view/1000

REPUBLIC HYDROMETEOROLOGICAL SERVICE OF SERBIA - RHMSS. 2010-2017. Hydological yearbooks, Part III: Water Qaulity.

ROUT, R.G. - SAHOO S. 2015. Role of iron in plant growth and metabolism. In Reviews in Agricultural Science, vol. 3, 2015, pp. 1-24. doi:10.7831/ras.3.1

ROWLAND, H.A.L. - OMOREGIE, E. - MILLOT, R. - JIMENEZ, C. MERTENS, J. - BACIU, C. - HUG, S.J. - BERG, M. 2010. Geochemistry and arsenic behaviour in groundwater resources of the Pannonian Basin (Hungary and Romania). In Applied Geochemistry, 2010. doi: 10.1016/j.apgeochem.2010.10.006

VARSÁNYI, I. - KOVÁCS, L.Ó. 2006. Arsenic, iron and organic matter in sediments and groundwater in the Pannonian Basin, Hungary. In Applied Geochemistry, 2006, no. 21, pp. 49-963.

VRANEŠEVIĆ, M. - ILIĆ, M. - BEZDAN, A. 2018. Irrigation water quality of the Tamiš River. In Annals of Agronomy, vol. 42, 2018, no. 1, pp. 17-25. Available at: http://polj.uns.ac.rs/sr/node/1423

XIUFU, S. - ZINATI, G. 2005. Management of Iron in Irrigation Water. Rutgers University, New Jersey Agricultural Experiment Station: New Brunswick, New Jersey. Fact Sheet FS516. Available at: https:// njaes.rutgers.edu/fs516/ 